\title{
Shoe-Throwing at Weddings
}

\section{James E. Crombie}

To cite this article: James E. Crombie (1895) Shoe-Throwing at Weddings, Folklore, 6:3, 258-281, DOI: $10.1080 / 0015587 X .1895 .9720312$

To link to this article: http://dx.doi.org/10.1080/0015587X.1895.9720312

$$
\text { 曲 Published online: } 14 \text { Feb } 2012 .
$$

Submit your article to this journal ๘

$$
\text { Џll Article views: } 4
$$

Q View related articles $\longleftarrow$

Citing articles: 2 View citing articles $\sqsubset$ 
investigation is worthless, being vitiated by imperfectly guarded methods, and by the preconceptions of the researchers. A very large portion of the phenomena falls within the province of both the Folk-Lore and the Psychical Societies. Of these phenomena there cannot be two varying canons of investigation. So that the "difference of method" which Mr. Lang regrets is a fundamental difference. If one method is right, then the other is wrong, and there is no fellowship between us save in crediting each other with honest desire to get at the truth. The psychical researcher represents a state of feeling, the folklorist represents an order of thought. Upon this, when writing $m y$ Address, it seemed to me well to lay stress, the more so as one strove to prefer large claims for the science of folklore; to show that, for humankind in its vast and momentous interests, there is no study of deeper importance. And in the degree that it falls into line with the general doctrine of evolution, it marches not with any method which tends to confusion rather than to order, and which postulates unknown causes to explain effects which known causes are sufficient to produce.

NoTe. - I am informed that the book entitled Soul Shapes, referred to in my Address (supra, p. 79), is not to be taken seriously.

\section{SHOE-THROWING AT WEDDINGS.}

BY JAMES E. CROMBIE.

Pelting a bride and bridegroom with old shoes when they start on their honeymoon is a custom we are all familias with, and in which many of us have participated. It forms one of a number of other throwing customs indulged in on the same occasion, and which differ from one another rather in the missile selected than in the motive of the assault. Of these other customs by far the commonest, and the one we are most familiar with, is the custom of throwing rice over 
the young couple when they go away. But when we come to analyse and compare these two customs we find the one differs from the other in two most important particulars. Firstly, the shoe-throwing custom differs from the ricethrowing one because the rice thrown is invariably new and good, and fit for consumption, whereas the shoes thrown are invariably old and worn, and unfit for further wear. Secondly, rice-throwing differs from shoe-throwing in its universality. For whereas we find the custom of throwing rice, or some other cereal, prevalent in almost every land, we find shoe-throwing practised mainly, I think, in those parts of the world inhabited by Englishmen or directly influenced by them, among the wandering gipsies of Transylvania, some parts of India, and one or two other places.

But if the two customs differ in some points there is not a shadow of, difference in the motive generally assigned for their performance. For both the (ordinary) shoe-thrower and the rice-thrower agree in saying that the throwing is done by them with a view to bringing luck to the persons assaulted: Now where does the luck come from?

If shoes were like rice or corn, one of the staple commodities of life, it would not be difficult to formulate at least one plausible theory: namely, that as the outset of one's married life is apt to be ominous of the rest of it, an abundance of the staple of life at the beginning is likely to be followed by abundance to the end, and that therefore those who throw rice symbolise by their action their desire that plenty may ever follow the young couple till death do them divide. But shoes are not a staple of life, and even if they were 1 don't know that we should have any right to decide off-hand that that was the reason why a volley of them brought good luck and why.we throw them at weddings. Take the case of rice. Although we do not as a rule throw rice except at weddings, we are rather singular in this respect. In many parts of the world no important undertaking is entered upon without the performance of 
this ceremony, and the reason assigned for it is quite as probable as, and much more amusing than, our own."

As Mr. Fraser says in his Golden Bough, over the greater part of the world the soul is conceived as a bird ready to take to flight. This is a conception all of us are familiar with, and it has left its trace in most languages, particularly in their poetry. But what is metaphor to a modern European poet was sober earnest to his savage ancestors, and is still so to many people. The Malays; for example, carry out this conception of the bird to its practical conclusion. If, they argue, the soul is a bird on the wing, it may be attracted by rice, and so prevented from taking its perilous flight. Thus in Java, when a child is put on the ground for the first time (a moment which uncultured people seem to regard as especially dangerous), it is put in a hencoop, and the mother makes a clucking sound as if she were calling hens. In the Celebes, marriage is another critical epoch; it is thought a bridegroom's soul is apt to fly away then, so:coloured rice is scattered over him to induce it to stay. And in general at South Celebes, rice is thrown on the head of anyone in whose honour a festival is held, with the object of detaining the soul, which at such times is in especial danger of being lured away by envious demons.'. Well may this rite have come to be regarded as bringing luck if it kept the soul in check, for what does it profit a man if he gain the whole world and lose his own soul?

Now, however ludicrous this bird theory of the soul may appear to us, and however probable it may be that the prevalerice of the idea may account for the rice-throwing, it appears to me that it won't account for our shoethrowing. At any rate, I don't think if any of us possessed a fowl and were anxious to keep it in our hen-run, we would throw our boots at it as a delicate way of tempting it to stay. Nor does it appear to me that any more possible or less contradictory explanation can be drawn, from following

Colden Bough, vol. iे. p. 124. 
out to its logical conclusion and applying to shoes the more common and civilised idea of corn being thrown to testify to the thrower's wishing the young couple plenty all their lives. On the same analogy, instead of oid shoes only being thrown on such a momentous occasion, nothing but new ones ought to be employed. For it is a sorry compliment to wish your newly wedded friends that they may all their lives have abundance of old boots and shoes. It would be kinder, surely, to keep a pair of new shoes for such an' occasion. Of course we may be told that once new shoes were probably thrown, but that we have got more sensible, and seeing the folly of the whole performance, and still desiring to keep up the traditional fun involved in it, have very economically and properly substituted old shoes for new ones. But is there any evidence of this?. If there is it will completely upset the theory I am going to propound, and some others besides. For I must admit that though shoes are not staples of life like corn or rice, they were at one time of much greater intrinsic value than they are at present.

Here are some examples. It is very extraordinary to find in how many different countries the staple wedding gift of the bridegroom to the bride or to her relatives is a pair of shoes. . According to a sumptuary law of Hamburg, enacted in I29I, the bridegroom was bound to present the bride with a pair. They almost played the part of our engagement ring, and were, as it were, evidence of betrothal: Among the Saxons of Transylvania it is still the custom for the bridegroom early in the morning of the wedding to send his intended a pair of shoes. And an ancient tradition cnjoins upon the girl, that she must treasure these shoes up, if she wants to be kindly treated by her husband, for he will not begin to beat her till they are worn out. ${ }^{1}$ In Greece, when the maiden has concluded the leave-taking with her friends in her father's house, the best man puts on her feet her boots, the gift of the bridegroom. Then the procession

'Land beyond the Forest, vol. i. p. 179 
starts for church, but before entering it the bridegroom's mother asks the maiden three times, "Bride, hast thou the shoes?" Lady Hamilton informs us that also among some of the American Indians, the braves when they visited their mistresses before marriage placed on her foot the " otoia," or shoe." But in many places the shoes are given to the relatives and not to the bride. Amongst the East Finns the young couple are attended to their bedroom by the entire company, but the bride's mother won't allow the young husband to go to bed till he has given her a pair of shoes. " In Bulgaria the bridegroom makes a money present to the relatives of the bride called the "oboutcha," or shoe money, and the father of the family buys with it shoes for the family community. This money is said to be a relic of the price paid by anyone for a wife to the clan from which she was taken." In Scotland, about the end of last century, the mere fact of possessing a pair of shoes testified to no small amount of affluence.: Both Burt ${ }^{b}$ and Somerville ${ }^{\circ}$ gave graphic pictures of the shoelessness of the lower classes in those days, and economists will smile at the then current wages, which for female servants amounted to only three half-crowns and a pair of shoes in the twelve months. And Banffshire farmers will understand how their greatgrandfathers made both ends meet when they read in the annals of Banff that the ploughmen in 1748 were content to labour for twenty-six shillings and eightpence a year, with two pairs of shoes. But there is another side to that hapy picture of low wages and low rents, for only forty years earlier the farmers of Aberdeenshire were chasing the cattle-lifting Caterans of Lochaber over the mountains into Perthshire, and redeeming their stock by paying the thieves

1 People of Turkey, vol. iv. p. Ino.

Marriage Rites, $3 \circ 3$.

- Hochzeitsgebraüche der Esten, p. I69.

"Letters from the North of Scothond Uraine," L'Anthropologie (1891).

- Somerville's Life and Times, pp. 326, 342. 
each a bag of meal and a pair of shoes. It would be fair enough to argue from these examples that shoes were once more valuable than now, and that their throwing at weddings may have meant something more than appears at first sight. But the great objection to such a theory is that there is not a shred of evidence to point to new shoes having ever been thrown, so we must look for the latent luck in some other quarter.

There have been several theories advanced to account for the shoe-throwing custom and its attendant luck. A great authority on marriage customs, the late Mr. McLennan of Edinburgh, thought that the custom was a survival of wifecapture, and recognised in the shoe-throwing the remains of the fight for the defence of the woman. ${ }^{8}$ - If we accept Mr. McLennan's premisses it is not difficult to explain how the idea of luck arose. Men do not fight for or defend any thing or person they do not value; on the other hand they will fight vigorously for anything they esteem. The vigour with which they contend for any object may therefore be taken as the measure of its value.

Suppose, in the old days, a wife-stealing party were to appear in any neighbourhood and run off with a woman, and her relatives made no defence; then the person run away with would feel that her friends did - not think her worth fighting for, and probably her lover would come to the same conclusion. If, on the other hand, there was a tremendous struggle, she would feel rather proud, and he would feel that she must indeed be a prize before such an uproar would be made about her. A stout fight would prove the value of the acquisition the man was making. It would be a good or lucky sign. Then suppose the same community to have advanced in civilisation, marriage by capture gives place to milder forms of wooing, but many of

1 Inverness Courier, August 17 th, 1847 ; of. Church and Social Life in the IIighlands, p. 20.

- Primitive Marriage (1865), p. 29. 
the old forms and customs of primitive times would still survive. We know they do. A certain superstitious value is attached to them, no marriage is complete where they are omitted, and, as is well known, any niggardliness, or parsimony, or breach of the recognised etiquette at the outset of the married life was held to be ominous of what would follow during the rest of it; it would therefore, supposing the shoe-throwing to have been a usual accompaniment of marriages and to have survived, have been unusual to have omitted it and consequently ill-omened or unlucky. Conversely it would be usual, well-omened, or lucky to have it performed. This, I think, is what Mr. McLennan means, and it is true enough if we accept his hypothesis and think that the shoe-throwing is really a relic of the fight for the bride.

For my own part I have never quite been able to follow him. For although I admit the prevalence of marriage by capture, I don't think there is any evidence to show that our ancestors made use of their shoes as weapons of offence in preference to anything else, and unless they had had an altogether excessive partiality for this particular form of missile it is a little difficult to see how, or why it should have survived to our day. Had stones been used we could have understood it, and an excellent example of , Mr. McLennan's theory would have been afforded by a Burmese custom quoted in McMahon's Far Cathay Farther India. It is customary there on the night of the wedding for a number of young bachelors to surround the young couples' house and pelt the roof. The explanation given by the natives is, that nine celestial beings or Brahmans, having elected to remain on earth, and having partaken of terrestrial food in place of celestial manna, degenerated from their pristine angelic form and taking the shape of mortals, five became men and four women. The fifth man naturally resented being left compulsorily single, and pelted the happy couples on their wedding night, and it is thought 
that the stone-throwing of the present day is done out of sympathy with the feelings of that archetypical bachelor of long ago. 1

Another explanation is given by Mr. Dyer in his English Folk-Lore, copied, I think, from Notes and Queries. "It has been suggested," Mr. Dyer says, "that the shoe is not thrown for luck only, but that it was originally a symbol of renunciation of dominion and authority over the bride by her father or guardian; and the receipt of the shoe by the bridegroom, even if accidental, was an omen that the authority was transferred to him. Thus in Deuteronomy (chap. xxv.), the ceremony of a widow rejecting her husband's brother in marriage is by loosing his shoe from off his foot; and in Ruth we find that it was the custom concerning changing; that a man plucked off his shoe and delivered it to his neighbour." In a, little book called The History of the Present Fews, we find a detailed account of this ceremony as practised among them. It follows in every detail the text of Deuteronomy, except that there appears to be a state shoe kept for the purpose nowadays: "The brother-in-law," it says, "puts on a shoe which the Rabbins used to have for the same purpose, and which will come upon any foot, and then the woman comes up to him, and with the Rabbin's assistance says in Hebrew these words to him out of verse 7 :

"My husband's brother refuseth to raise up unto his brother, a name in Israel, he will not perform the duty of my husband's brother."

And he answers her:

"I like not to take her."-Verse 8.

Then she stoops down, and unties and puts off his shoe, and throws it upon the ground and spits before him; and the Rabbins saying the words before her she goes on and says:

"So shall it be done to that man that will not build up his brother's house. And his name shall be called in Israel, The house of him that hath his shoe loosed." 
These words she repeats three times, and the standersby cry out every time, "He that hath his shoe loosed."

It will be noticed that neither in the ancient nor in the more modern custom is there any hint of throwing the shoe at the man. The whole ceremony consists in simply untieing and removing his shoe. In a great many parts of the world to-day it is quite a recognised part of the wedding festivities for the bride to remove her husband's boots. It is admittedly done with a view to symbolising the woman's acceptance of her marriage vows, and recognition of her position of subjection to her husband's wishes. Such a sentiment may appear very revolting to the "New Women," who are attracting some notice at present, but it may interest them to know that in down-trodden Russia even the old woman rebels against the idea of inferiority implied in the menial duty, and while she dutifully. removes her lord and master's boots as a sign of subserviency, never fails to deal him a sound clout on the head with one of them, by way of showing that she is not one whit inferior to him. ${ }^{1}$ It is obvious, however, that no such ideas can be involved in the Hebrew custom, for the woman there undoes the man's shoe as a symbol of undoing the tie that binds her. to him, and by so doing regains her freedom, whereas in the Russian custom it is the reverse.

The key to the solution of the problem is afforded us by the late Professor Robertson Smith in his book on Kinship and Marriage, in which he points out an excellent reason for the choice of a shoe on such an occasion, in preference to any other article of dress. According to Professor Smith, the words in Hebrew for shoe and wife are identical, and if that is so, what fitter means of symbolising the casting off of a wife (and the instance of Ruth is a case in point) than in removing and casting off the man's shoe who failed to respond to the duties of the levirate. A Bedouin

Ralston, Songs of the Russian People, p. 302 ,
Kinship and Marriage, p. 26g. 
form of divorce is, "She is my slipper, I have cast her off." 1

Mr. Dyer does not appear to have been aware of this coincidence when he selected this particular passage for the foundation of his theory. A much better illustration of what he wanted to show lay ready to his hand in the sixtieth Psalm:

\footnotetext{
"God hath spoken in His holiness; I will rejoice, I will divide Shechem, and mete out the valley of Succoth. Gilead is Mine, and Manasseh is Mine; Ephraim also is the strength of Mine head; Judah is My lawgiver; Monb is My washpot; over Edom will I cast out $\mathrm{My}$ shoe: Philistia, triumph thou because of Me." Who will bring Me into the strong city? who will lead Me into Edom?"
}

The casting out of the shoe over Edom is regarded by some as symbolical of abandoning it; for my own part I think it means the reverse, and that it is symbolical of the intention to conquer it, and the symbolism of throwing a shoe over it is tantamount to walking over it. Be that as it may, what has this Jewish custom to do with us? Is there any evidence of shoe-throwing as symbolical of authority having been practised in our country? There is. We read in Gibson's Camden that the O'Cahans had the right to throw a shoe over the head of the O'Neal when he was chosen chief. It is a curious performance, and the only apparent motive for it must have been to mark the superiority of the thrower and symbolise his suzerainty. If that is so, then the shoe-throwing on the part of the bride's peo. ple when the young couple set out on their marriage jaunt may have been intended to symbolise, that, although she is leaving her father's house, he does not renounce his ownership and authority over her. There is a good deal to be said in support of this theory. It is a common method of symbolising absolute authority for the person in the superior position to put his foot on the neck or head of the inferior, who kneels before him. Throwing a shoe over him may be

I Burckhardt, Bedonins, vol. ï. p. 113 . 
taken to be a more expeditious way of attaining that end. It is also true-we have it on the authority of the Boulster Lecture-that at Anglo-Saxon weddings it was the custom for the bride's father to deliver one of her shoes to the bridegroom, who touched her on the head with it to show his authority. But in spite of the evidence Mr. Dyer produces in support of his theory, we are inclined to reject it, because there is at least one occasion on which shoe-throwing is performed, and in which Mr. Dyer's theory will not apply. - It is a time-honoured custom to throw an old shoe after any: one setting out on a journey to bring him luck.

John Heywoods in his works (A.D. 1598) says :

"And home againe hitherwards quicke as a bee,
Now for good luck, cast an old shoe after me."

Where can possession or renunciation come in here? Clearly it will not apply. Must we therefore look for another theory to account for the shoe-throwing in this instance? It seems to us that the same motive will answer both, if we can get hold of the correct one. Mr. Dyer and most other investigators have proceeded on the assumption that the shoethrowing is a marriage rite only. We prefer to start on the assumption that shoes are thrown at marriages, not so much because the occasion is a marriage, as because the occasion is one when a new departure in life is being taken. If we can explain why shoes are thrown for luck when anyone sets out on a journey we maintain that we can explain their use at marriages too.

I said at the opening of my paper that rice and shoes were only two of quite a 'number of other things thrown at weddings with a view to bringing luck. I told you that one explanation given for the throwing of rice was that it was one of the necessities of life. Now if corn is one of the great necessities of existence, water is another, and it will not be surprising to find instances of the sprinkling of bride and bridegroom with it. Mr. Rodd gives the 
following account of a Rhodian wedding.. When the young couple enter their own house, "the husband on arriving dips his finger in a cup of honey and traces a cross over the door, while those present cry aloud, 'Be good and sweet as this honey is.' : A pomegranate is placed on the threshold which the young husband crushes with his foot as he enters followed by his wife, over whom the wedding guests throw corn and cotton seeds and orange-flower water." In Albania the same author tells us that on the Monday following the wedding, "the wedding guests witness the symbolical eating of bread and honey together by the bride and bridegroom, and then a procession is formed to the village well, where they sprinkle one another with water." . Risley, in the work already quoted, ${ }^{2}$ relates how the bridegroom in the Mahili caste approaches the bride's house mounted on the shoulders of a male relative, and bearing on his head a vessel of water, how h'e is met at the entrance by the bride's brother similarly mounted and also carrying a vessel of water, and how the two cavaliers sprinkle one another. But just as we found that rice was sprinkled on other occasions than weddings, so we find it with water. Students of German folk custom will recollect how at the spring ploughing in Prussia, when the ploughman and sowers returned in the evening from their work in the field the farmer's wife or servants used to splash water over them. In the district of Cracow, when a woman at harvest time builds the last sheaf of corn, she is at once hailed as the "Baba" or "Old Woman" who makes the corn grow, is herself wrapped ip in the sheaf, so that only her head projects out of it, and thus encased is carried to the farmhouse in the last waggon, where she is drenched with water by the whole family. The reason for this is very interesting. In every farm there is believed to reside a corn spirit. "As field after field is cut, it is chevied from stalk to stalk, till at last it is driven to the last handful in the last field

1 Customs and Lore of Modern Greece, pp. 99, 105.

- Tribes and Castes, vol. ij. p. 4I.

vor. vi. 
and is cut down in it. The person dressed up is for the time being regarded as the incarnation of the spirit of fertility, and with a view to making the crop turn out well, and secure another good season, the peasants water her just as they would the growing corn itself. . As Mr. Fraser says, the rite is essentially one of sympathetic magic." It seems to me that we can account for the water-throwing at weddings on much the same lines as the sprinkling of the Baba, and that it too is a case of sympathetic magic, and that the idea prompting its performance is the same materialistic one of fructification. For we must never forget that a well-filled quiver was the proudest boast of the pre-Malthusian home, and a barren union the greatest disgrace, and that most of the curious customs at weddings are engaged in with a view to preventing such an untoward event. An excellent example of this is afforded by one of the customs just cited. ". It will be recollected that at the Greek wedding we spoke of a little while ago, in which water was thrown, a pomegranate also figured in the home-coming ceremony: We were told the young husband crushed it with his heel on the threshold. Now the pomegranate is a famous symbol of fertility, and the crushing of it on the threshold and letting free its seeds is a highly symbolical proceeding, intended to influence by sympathy the young couple. It is also a very remarkable fact, and strongly confirmatory of the view we take of the throwing of water at weddings, that the Hottentot maidens must run about naked in the first thunderstorm after the festival of their maturity is celebrated. The rain pouring down over the whole body of the girl who receives it. is believed to have the virtue of making her fruitful and rendering her capable of having a large offspring.? But it may be asked, What has this to do with shoes? Is it suggested that shoes are thrown at weddings with a view to bringing luck in the form of offspring? And if so, can evidence be pro-

Colden Bough, vol. i. pp. 339, 340, et seq.
Hahn, Tsuni-goam, p. 87 . 
duced of a superstition pointing to their being believed to exercise a similarly beneficial effect upon animal life and vegetation?

It is our intention to suggest that this is one of the indirect objects of the shoe-throwing, and we can show some examples of shoes being considered to have a potent influence on vègetation and on animals. The most extraordinary of the latter is met with among the Esquimaux, who are in the hábit of attaching a piece of an old shoe, which has once been worn by European sailors, to their wives to make them prolific mothers. In China, Doolittle ${ }^{1}$ describes a curious visit which women pay to the shrine of "the mother" goddess in order to borrow one of her votive shoes. These shoes are dedicated to the goddess by women who have been blessed with family, Each suppliant burns incense and prays that she may become a mother too, and vows if her prayer is answered, and if the shoe she carries away does bring about the desired result; she will present another exactly like it to the divinity when she returns the one temporarily lent to her. Grinnell, ${ }^{3}$ speaking of Blackfoot Indians and the ceremony of gathering the tobacco crop, says that the first plant is gathered with great ceremony. "It is plucked by a man who ties it to a little stick, and under the tobacco to the stick he ties a baby's mocassin." Why? "The little tobacco patch is sown in spring, and after doing so the Indians move away after the buffalo: From time to time while they are absent the men gather in some lodge to perform a special ceremony for the protection of the crop. Each man holds in his hand a little stick. 'They sing and pray to the sun and "Old Man," asking that the grasshoppers and other insects may not eat their plants. At the end of each song they strike the ground with their sticks as if killing grasshoppers and worms. It has sometimes happened that a young man has said that he

I Doolittle, Social Life of the Chinese, vol.' i. p. II5.

- Grinnell, Blackfoot Lodge Tales, p. 270. 
does not believe that these songs and prayers protect the plants. 'To such an one a medicine-man will say, 'Well, you can go to the place and see for yourself.' The young man goes. When he comes to the side of the patch and looks on it he sees many'small children at work there killing worms.". These children are the genii of the place, and the tying of the shoe on the stick is undoubtedly done with the idea of pacifying them and securing their goodwill, or in other words a good crop. It is in fact a variant of the Baba of the Cornfield. Herodotus tells us that the Chemmitze of the Thebaid claimed Perseus as of Chemmitic descent, and they affirmed that Perseus frequently appeared to them on earth, and that a sandal worn by him was sometimes found which was two cubits in length, and that after its appearance all Egypt flourished. ${ }^{3}$ In this instance the good crops may be said to have been due rather to the magical passing of Perseus than to the sandal itself. No such explanation will, however, meet the curious Esquimaux custom of hanging bits of old boots about their wives as talismans. In the explanation of this custom is involved the explanation of shoe-throwing at weddings and on other occasions, as well as a host of other minor customs and superstitions in which shoes play a part. The secret lies in the animism of the shoes. Now what do we mean by that? It is a wellknown fact that among peoples low. down in the scale of civilisation a certain magical virtue or power is attached to anything that has been made by, owned by, or most of all worn by another. Nor have more advanced religions managed to shake themselves entirely free of the same idea. We are all conversant with the story of Elisha and the marvels he wrought with Elijah's cloak. A few months ago the world was wondering at the faith or superstition that drew so many thousands to Treves to be healed by gazing on the so-called Holy Coat; just as, nearly four

HEerodotus, ii. 91. 
hundred years ago, our ancestors used to flock to Canterbury to gaze with reverence, not on the ancient cathedral, for it was young then, but on the shoes of St. Thomas, the relics of its saint.: But I want to show you another phase of this superstition. 'So far as we have gone we have only met with instances of the erstwhile possessor of the cloak or shoes, influencing us by means of these. The converse is less likely to be familiar to us, but it is none the less true and hardly less common. Indeed, the idea that if one could possess oneself of an article that had once belonged to another, the mere possession of that article would give the possessor the most extraordinary power over the original owner for good or evil, is more common than the other among peoples in the lower grades of culture, and is still frequently met with in the necromancy and magic of European peoples of to-day. In Germany, Grimm tells us, in the district of Saalfield, old women often cut out a turf a foot long on which an enemy had trod, and hang it up in the chimney under the impression that the enemy will shrivel up just as the turf does, and ultimately die $^{1}$ a lingering death. While in Italy Mr. Leland says that a popular cure for the gout is to spit thrice on the footprint of the person to be cured, and at the same time to repeat a spell. These may appear extreme examples, but if we can injure or benefit a man by dealing with his footsteps it stands to reason that he could do it through his shoes, for shoes are merely footsteps glorified.

Nor is it necessary to go far afield for an example. In the middle of the 17 th century the Scottish presbyteries were much exercised by the doings of sorcerers and charmers within their bounds, and we meet with the following amusing case in the year 1644 in the Presbytery Book of Strathbogie." It is somewhat a long story, and deals with the "cloddings,"

1 Grimm, Teut. Myth., p. 1798.

I'resbytery Book of Strathbogie, p. 50. 
or, as we should term it, breach of the peace, occasioned in the respectable household of Alexander Christie by a sorcerer called Patrick Malcom. Walter Brabner, an orderloving neighbour, called as witness, deponed that he had seen the clodding, and fearful trouble raised in the house and continued for the space of twenty days, and he proceeds to tell the cause. Need we say there was a woman in it? But we shall let Walter speak for himself. "There was a servant woman with the said Alexander Christie whom the said Patrick (the accused) desired to go with him, and upon her refusal he told her that she should not win her fee that year, and likewise told her what she had in her ambrie, it being closed, whereupon the clodding began that night, and continued till they were forced to remove the said woman out of the house." Walter Brabner is dismissed, and the reverend fathers call on a certain Alexander Chrystie. Alexander gives more interesting details. "He depones that Patrick Malcome came and 'ludged' in his house, where he urged his servant woman, Margaret Barbour, to committ filthines, with him (as the woman declared) and required her left shoe, and he should cause her follow him, which the woman refusing, the clodding began, and continued till she was removed." From Margaret Barbour clinging to her virtue and her left shoe, we turn to Germany, where we find that in Hesse, if one wanted to fetch a comrade back from a foreign land, one had merely to boil his boots for four days in a pan of water drawn from a stream against the current. At the end of the fourth day the owner is guaranteed to appear, but the historian does not condescend on how he takes the treatment his boots have been put to.' Now why does the possession of the shoe give such in; fluence over the owner that he or she can be led away at the will of the man who chooses? Let us take an extreme case again. In many parts of the world a mother-in-law

'J Grimm, op. cit., p. sog3. 
does not look at or come near her son-in-law. Melanesians have this curious taboo, and to such an extent is it carried that a mother-in-law will not go along the sands. where her son-in-law has preceded her till the tide has completely effaced his footsteps. His personality seems to linger in his steps. If he had been dead we could have.expressed our meaning at once by saying his ghost haunted; them. The following example will make our meaning clearer; and it, and the others. which follow, will show how closely a person's spirit is believed to be bound up in his shoes; for that is what we mean when we talk of the animism of shoes. In China, when a girl who has been betrothed dies : before the wedding day, the man whom she should have married performs the custom of asking for her shoes. He goes to her parents' house, and with much weeping demands a pair of shoes she has recently worn. These he carries home in state, stopping at each street corner to call out her name and invite her to follow. On arriving at his home he informs her of the fact. . Then a chair is arranged before a table, the shoes are placed either on the chair or under it, incense is burned on the table, and finally a tablet is placed to her memory among the other ancestral tablets of the family. ${ }^{1}$ Everything is done just as if she were present and wore the shoes. . But this uncanny belief in dead men living on in their shoes is not confined to China. A most remarkable example of the same idea attracted a good deal of notice during the trial of the Arran murder case at Edinburgh in November, 1889 . The circumstances of the case may be stated very briefly. Two young men set out on a walking excursion in Arran, and only one of them was ever seen again alive.: The body of the other was found in a lonely spot concealed under a heap of stones. Suspicion turned on the survivor, a man named Lawrie, and he was .arrested; tried, and condemned to

' Doolittle, Social Life of the Chinese, vol, i. p. 102. 
penal servitude for life. But what is of interest to us, is a little episode that took place during the trial. The clothes of the murdered man were produced in court, but when they were examined it was noticed his boots, were not there. There was at once a call for them, and an explanation demanded for their absence. After some pressing it appeared that they were not forthcoming because the local constable had buried them on the sea-shore between high and low water mark. All the efforts of counsel failed to elicit any explanation of this extraordinary "proceeding. The man would only admit that by the orders of his senior officer he had put them out of sight.

The probable explanation is that it was done with the idea of preventing the ghost of the murdered man from walking, for the removal of the shoes of a person who has either met with a violent death or is suspected of being a vampire, and making away with them, is not an uncommon northern superstition... The foreshore, a sort of no man's land, is just the spot that one would expect to be fixed on for their disposal.

In the Museum of Northern Antiquities at: Copenhagen may be seen the mummified corpse of a woman, said to have been Gunhild, who was treacherously seized by Harold Blue-tooth and drowned in a bog. Whether Gunhild or not, this body was dug out of a peat moss, and now lies in a wooden sarcophagus despoiled of her garments, "like a statue carved in oak fresh from the bogs of Hibernia." The. clothes found on her are also preserved, along with the wooden hooks by which she was pegged down, "to allay all fear of her rising again to torment her murderer... The left shoe was removed, too-a very necessary precaution."1 These examples, I think, prove pretty conclusively a widely spread belief that a person's ghost; soul, spirit, or life principle exists apart from him in his shoes.

' Marryat, Jutland, vol. i. p. 65 . 
Next I wish to refer to another belief common among primitive peoples, that this soul or life principle can be transferred to others and absorbed by them to the great advantage of the absorber. This can be best illustrated by reviewing some instances of superstitions regarding blood. We are ourselves accustomed to talk of the life's "blood." We see how, when a man is wounded and some severance of a great artery takes place, he speedily bleeds to death. It is therefore not a very illogical proceeding to regard the loss of blood as the cause of death, and, conversely, the retention of it as one of the causes of life. Such is the view many uncultured people take. Nor is it very surprising that peoples holding such views should conclude that in event of a person's being seriously unwell and stricken down with some disease, the nature of which they do not understand, 'his life may be prolonged and : new vigour inspired into his wasted frame by pouring over him the blood of vigorous individuals. The Australian aborigines carry the idea with them to the grave; and at a funeral the relatives gash themselves over the corpse till it and the grave are covered with their blood. : This is said to strengthen the dead man, and enable him to rise in another country. ${ }^{\mathrm{l}}$. An even more interesting blood custom takes place at a wedding among the Gallas, a tribe in the northeast of Africa, which deserves our special attention. When the bride is brought home, Paulitschke tells us, an ox is slaughtered, and bride and bridegroom dip their. fingers in the blood and then paint one another, turn about, upon the breast and the lower part of the body (geschlechtsteilen) in order to procure strength and blessing for the expected offspring. Thereafter relatives of the bride paint her all over with blood so that she may have strength when she comes to bear children, and the bridegroom gives the finishing touch by pouring blood down the back of her

1 Fraser, Totemism, p. 81, quoting Nat, Trans. of S. Aust.; 277. 
neck.? Even a bonnie bride after such busking must be a rather sorry-looking object; and I would not have introduced her to your notice had it not been, first, that it is such an excellent example of the magical power of life principle believed to exist in blood, and the possibility of its being communicated to others; and, second, that we have found shoes being used with exactly the same end in view.

In fact we may go farther and say that the shoe is sometimes a more potent "medicine" than even blood itself. The following interesting veterinary example from Crooke's Religion and Folk.Lore of Northern India (p. 4I) will show this. In Sirsa, when a horse falls sick, the cure is to kill a fowl and let its warm blood flow into the animal's mouth; but if this cannot be done quickly, it is sufficient for a man to take off his clothes and strike the horse seven times on the forehead with his shoe. The combination of the magical use of the shoe with the well-known curative one of blood is most interesting. It throws unexpected light on a difficult question, and seems to us to go far towards solving the problem of where the luck of old shoes comes from. Fortified with this piece of evidence, we ask again, why do the Esquimaux hang parts of the old shoes of European sailors about their wives to make them prolific? Why is it that an Esquimaux father, who wants his young son to become a brave man, and good hunter like himself, insists on the boy's eating his meals off a platter placed on the father's boots? Both are very curious notions, but if "we reason from the analogy of blood, and bear in mind the idea that the life or spirit or essence of a wearer lingers on in his boots or shoes, just as it does in blood, and might be communicated, we can see daylight through both Esquimaux customs. The Esquimaux regard, or did at one time regard, European sailors with particular reverence as almost divine

I Faulitschke, Ethnog. nordost Atrikes, p. 252. 
beings. They were cleverer, stronger, and in every way superior to themselves. Then they would argue that if that were the case, part of their essence would linger even in their discarded shoes, and if these discarded shoes were attached to their wives some of it would pass to them, and endow them with similar qualities and make them strong. It is manifestly also the same idea that prompts the Esquimaux father to make his little boy eat off his boot. He does so in the hope that some of his own spirit, life, or essence, 'with all the qualities that distinguish him, may pass into the boy's food, and be absorbed by him in it, and that so the child may become as good, as wise, as strong as 'he is himself.' . We meet with similar ideas nearer home. It was, and still is, no doubt, the custom in some parts of Germany for a woman about to become a mother to wear her : husband's shoes when her hour comes, in order to facilitate her labour. The idea being that as the husband is the stronger, she may by wearing his boots obtain some of his strength, and thus be more fitted for the ordeal in store for her. It would be difficult to find a closer parallel to the Esquimaux custom.

And now, bearing in mind the belief in the existence of the life principle in shoes and the possibility of its being communicated, let us turn our attention once more to our practice of throwing them at weddings. By doing so we should be doing for the young couple, in a more pleasant way, exactly the same as the relatives of the Galla bride did for her, when they anointed her from top to toe with the bullock's blood. We should be doing for them with shoes what our Aryan ancestors did for their cattle with the sacred parna rod, and what the herdsmen of Sweden and The Mark do to this day, when on the first of May they watch on which branch of the mountain ash the sun first strikes, and then cutting it down, beat the yearling heifers with it on the loins and haunches, repeating at each stroke a verse in which they pray that as sap comes into the birch so may milk fill 
the cow's udder. ' We should be doing with shoes what the Romans did in ancient Rome at the festival of the Lupercalia, when the boys armed with strips of the skin of the slaughtered goats used to rush through the city, striking all they met, and where women, particularly those who desired to be made fruitful, placed themselves naked in the way and received the blows of the Luperci on their palms.

We should in fact be supplementing the vital strength of the young couple at a most critical period of their career, when heavy calls are likely to be made upon it, by adding a little of our own supply of vitality to theirs. And if throwing a shoe was efficacious, then it would be efficacious at any other time when any undertaking of a risky nature was going to be entered on. And what undertaking was more risky in the old days than a journey? "Criticising Ben Jonson's lines,

\section{"Would I had Kemp's shoes To throw after you,"}

Grose suggested that Kemp was probably a lucky individual, and that accounted for the desire to hurl his shoes. No doubt, if Kemp had been a lucky individual, it would have rendered his shoes more powerful talismans. - But after all, what was it that made even Kemp's shoes lucky? It was the veiled and forgotten belief that Kemp's life or essence lingered on in them, and could be communicated. Therein lay their luck. That is why old shoes are always thrown at weddings. It was through no motive of sordid economy. Economy is the last thing thought of on those occasions. Old shoes were thrown, to begin with, because men believed in their animism, and we throw old shoes still, and think that they are lucky, because, in spite of all our education and all our science, we have not been able to shake ourselves

I Kelly, Indo-European Traditions and Folklore, p. I60, 
entirely free of the old beliefs and practices of the dark days of the childhood of our race. But it may be objected that there is no apparent necessity now for hitting the individual, and it may be asked how, if there is no contact, the life can be communicated by merely throwing the shoe after any one. That such, should be the case by no means vitiates our theory. It is a symptom of the disintegration and decay in which all folk-customs fall, when they have to struggle against the milder manners of the men and women of to-day. We find it in the case of the blood rite, we find it in the case of saliva, we find it in everything. Customs like times change; the most surprising thing is that they change so little.

- Since writing the above I have had brought under my notice a series of articles on shoes which have recently appeared in Zeitschrift des Vereins fur Volkskunde, vol. iv., which will be found of great interest. 